\title{
Field performance of various Pinus radiata breeding families established on a drought-prone site in central Chile
}

Sergio E. Espinoza ${ }^{1 *}$, Carlos R. Magni ${ }^{2}$, Rafael A. Rubilar ${ }^{3}$, Marco A. Yañez ${ }^{4}$, Rómulo E. Santelices ${ }^{1}$, Antonio M. Cabrera ${ }^{1}$ and Miloš Ivković ${ }^{5}$

\begin{abstract}
Background: Pinus radiata D.Don is in its third generation of selective breeding on contrasting site types in central Chile, creating interest in its responses to selection and any differential adaptation to site types. We studied the phenotypic variability of growth traits, survival and six ecophysiological traits in 30 open- and controlpollinated families, representing two breeding regions and three breeding generations, in a 2-year-old $P$. radiata field trial on a sandy soil in the Mediterranean drylands of Central Chile.

Findings: Growth, survival and the ecophysiological traits did not differ between the regional origin of the breeding populations. However, breeding-generation effects were significant for height and diameter. As expected, growth traits showed progressive improvement with successive generations. Individual-family effects were evident for all traits except one ecophysiological trait.

Conclusions: Breeding has evidently improved early growth performance in the field, despite no clear effect of regional breeding population, but no such effects were observed for the ecophysiological traits. Despite the current study demonstrating considerable family variation at age 2 years, it is unclear how these results relate to performance of mature trees in the field.
\end{abstract}

Keywords: Breeding, Gas exchange, Radiata pine, Sandy soils, Survival, Growth rate, Ecophysiology

\section{Findings}

\section{Background}

Pinus radiata D.Don is a very widely planted species that grows on a broad range of soil types and climatic conditions (Mead 2013). The species was purposefully introduced in Chile in the early 1890s (Contesse 1987), with one consignment presumed to have come from the Monterey provenance of California (Burdon 1978), and was initially established in coastal sites (Camus 2006), including poor, sandy sites (Albert 1900). A breeding programme was implemented in Chile during the mid1970s using a recurrent selection scheme that consists of successive cycles of selection of candidate trees and their crossing. Pinus radiata has undergone three

\footnotetext{
* Correspondence: espinoza@ucm.cl

${ }^{1}$ Facultad de Ciencias Agrarias y Forestales, Universidad Católica del Maule,

Avenida San Miguel, 3605 Talca, Chile

Full list of author information is available at the end of the article
}

generations of breeding for growth rate and form to date. Some unintended changes in wood properties associated with breeding ( $\mathrm{Li}$ and $\mathrm{Wu} 2005$ ) and evidence of important differences among populations and breeding generations in response to water stress at the nursery stage (Espinoza et al. 2013, 2014, 2016) have been reported. However, no studies have investigated if such differences persist when different breeding generations of the species are established in complex field environments, where multiple stresses co-occur. Approximately $40 \%$ of the annual plantation restocking in Chile is done with genetically improved seedlings. Thus, the variability of physiological traits needs to be evaluated, as it can impact on stand productivity, especially in a context of climate change.

Differences in growth, wood density and other traits according to breeding generation have been extensively reported for P. radiata in different field trials (e.g. Mead et al. 
2013 and references therein). Differences in physiology have been reported in species such as Pinus taeda L. (Yang et al. 2002), but no studies have been reported hitherto for $P$. radiata. Gas exchange $\left(\mathrm{CO}_{2}\right.$ assimilation) values of firstgeneration half-sib families of $P$. taeda (McGarvey et al. 2004) were similar to those reported for unimproved material (Cregg et al. 1993). These results could preliminarily indicate that changes in growth associated with breeding are not necessarily associated with changes in easily measured ecophysiological traits.

This paper examines the possible consequences of breeding on growth and gas exchange in $P$. radiata populations in Chile, by examining phenotypic variation in early growth and physiological performance of trees established on a drought-prone site. We chose two populations and three breeding generations of $P$. radiata, because population- and breeding-generation differences in growth, morphology and biomass allocation under drought stress in nursery conditions have been well documented (Espinoza et al. 2013, 2014, 2016). Espinoza et al. (2013) reported that interior and coastal breeding populations of $P$. radiata in Chile displayed different responses to drought, which were also related to the breeding generation of the families under study (Espinoza et al. 2016). First-generation seedlings from the coastal population displayed a higher survival than the interior population when exposed to water shortage, but survival decreased in the following breeding generations. Conversely, survival increased from the first to the third generation in the case of the interior population. However, there is less understanding of whether differences observed between breeding families in response to water stress in a nursery then persisted in the field. The present study reports on early results from a long-term field experiment involving a subset of the families used by Espinoza et al. (2016). Above-ground growth and some additional ecophysiological traits were examined. We tested the hypothesis that selection for growth has improved growth over breeding generations but has exerted no change in easily measured ecophysiological traits.

\section{Material and methods \\ Plant material}

Two populations of $P$. radiata were selected, one from an interior and one from a coastal site in Central Chile. A phenotypic ranking based on height for seedlings under nursery water stress conditions was constructed using the same data set of Espinoza et al. $(2014,2016)$. A subset of 30 families were then selected from the total 98 families used in the previous nursery experiment (10 families from each of the upper, middle and lower portions of the ranking). All 30 families are included in the current Forestal Mininco Company breeding programme and were selected for volume, form and wood density. Seeds were obtained from the following three sources:

1. Five open-pollinated families were obtained from plus trees in plantations in coastal sites $\left(37^{\circ} 02^{\prime} \mathrm{S}\right.$, $73^{\circ} 07^{\prime} \mathrm{W}$ ) and interior sites $\left(37^{\circ} 06^{\prime} \mathrm{S}, 72^{\circ} 30^{\prime} \mathrm{W}\right.$ ) (i.e. first generation of breeding),

2. Eighteen open-pollinated families of seed parents from coastal and interior sites were obtained from an open-pollinated seed orchard (i.e. second generation of breeding), and

3. Seven control-pollinated families of parents only from coastal sites were obtained from a controlpollinated seed orchard (i.e. third generation of breeding).

Seeds were soaked in distilled water for $24-48 \mathrm{~h}$, and those that floated were excluded because they were not considered to be viable. The remaining seeds were sown in $140-\mathrm{mL}$ pots with a mixture of composted $P$. radiata bark and perlite $(8: 2 v: v)$, combined with a slow-release fertiliser (Basacote ${ }^{\mathrm{Tm}}$ Plus $6 \mathrm{M}$, at $3 \mathrm{~kg} \mathrm{~m}^{-3}$ ). Seedlings were grown in the Centro de Biotecnología Forestal from Forestal Mininco Company (Los Angeles, Central Chile, $37^{\circ} 28^{\prime} \mathrm{S}, 72^{\circ} 16^{\prime} \mathrm{W}, 171 \mathrm{~m}$ a.s.l) following routine seedling production system of the company. Families were randomly allocated, and two replicates of 88 seedlings per family were cultivated under homogenous conditions. After germination, seedlings from each family were watered daily according to the nursery prescriptions (i.e. twice per day) and cultivated for 9 months.

\section{Site description and trial establishment}

The trial was established in the Alcapan locality (Los Angeles, Central Chile, $37^{\circ} 12^{\prime} \mathrm{S}, 72^{\circ} 10^{\prime} \mathrm{W}, 200 \mathrm{~m}$ a.s.l.) on a flat site. Soils of the nearby area are sandy (93\% sand) with both very low water-holding capacity (less than $150 \mathrm{~mm}$ at a depth of $3 \mathrm{~m}$ ) and low levels of total nitrogen (Huber and Trecaman 2004). Mean annual precipitation is $1154 \mathrm{~mm}$ and winter precipitation (i.e. from June to August) is $586 \mathrm{~mm}$ (Espinoza et al. 2013). The summer months (i.e. from midDecember to mid-March in the Southern Hemisphere) are typically hot and dry (summer mean daily maximum temperature is $27{ }^{\circ} \mathrm{C}$ ). The length of the dry period exceeds 7 months and usually occurs from September to April. The trial was planted on Forestal Mininco Company land; thus, the routine silvicultural treatments of the company were applied throughout the trial. Site preparation consisted of subsoiling at up to $50-\mathrm{cm}$ depth. Ground vegetation was scarce because of the dry conditions of the site during the growing season and good weed-control operations. Granular NPK fertiliser was applied by hand at the 
planting hole (Basacote ${ }^{\text {TM }}$ Plus 9M, at $25 \mathrm{~g} \mathrm{plant}^{-1}$ ). The selected 30 open- and control-pollinated families were planted with shovels in July 2013 following a randomised complete block design with nine block replicates of 30 families and 9-tree square plots each (Fig. 1). Seedlings were planted at a spacing of $3 \times$ $3 \mathrm{~m}$, giving a plant density of 1111 stems ha ${ }^{-1}$ (i.e. 9 blocks $\times 30$ families $\times 9$ seedlings per family $=2430$ ).

\section{Survival and morphological assessments}

Tree height $(H)$, root collar diameter at the ground line $(D)$ and survival (SUR) were measured on all trees at age 2 from planting. Tree volume (VOL) was derived as VOL $=D^{2} H$. The $H$ and $D$ measurements were collected in June 2015 because height growth ceased at the site during this month. Measurements were recorded using height pole and digital calipers, respectively. Survival was measured as a categoric trait (i.e. live seedling $=1$, dead seedling $=0$ ).

\section{Gas-exchange measurements}

In February 2015, predawn water potential $\left(\Psi_{\mathrm{pd}}, \mathrm{MPa}\right)$, net photosynthesis rate $\left(A_{n}, \mu \mathrm{mol} \quad \mathrm{CO}_{2} \quad \mathrm{~m}^{-2} \mathrm{~s}^{-1}\right)$,

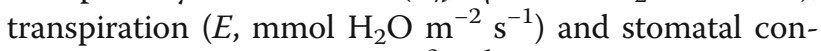
ductance $\left(g_{\mathrm{s}}, \mathrm{mmol} \mathrm{H}_{2} \mathrm{O} \mathrm{m} \mathrm{m}^{-2} \mathrm{~s}^{-1}\right)$ were measured on a random subsample of 150 trees (i.e. 5 blocks $\times 30$ families $\times 1$ tree per block per family $=150$ trees) with a pressure chamber and a portable photosynthesis system (model Li-6400XT, LI-COR Inc., Lincoln, NE, USA). One fully developed and sun-exposed fascicle was collected in the upper third of each plant and immediately placed in the 250-mL chamber. Measurements were conducted sequentially by block to partition diurnal environmental variation. Measurements were taken between 1100 and 1400 h. Gas-exchange measurements were corrected on a fascicle-area basis following Ginn et al. (1991). Briefly, the fascicles are assumed to have a cylindrical shape, with all the needles having the same cross-sectional dimensions. Intrinsic water use efficiency
(WUEi, $\mu \mathrm{mol} \mathrm{CO}_{2} \mathrm{~mol} \mathrm{H}_{2} \mathrm{O}^{-1}$ ) was calculated as the ratio between the net photosynthetic rate and the stomatal conductance.

\section{Data analysis}

All traits except survival were analysed with the general linear model approach (GLM) in analysis of variance. We used the type III sum of squares for the F-tests, which was computed using SPSS version 18.0 software (IBM, USA). Group comparisons for survival were performed using a chi-square test. Physiological data for WUEi were corrected for plant size $(H)$ as a covariate. The model terms were fitted according to the hierarchical design of the experiment, considering families as nested within breeding generations, which in turn were nested within populations. Preliminary results showed no significant effects of the block and its interactions, so these terms were removed from the model. The model used was:

$$
Y_{i j k l}=\mu+P_{i}+G(P)_{i j}+F(G(P))_{i j k}+e_{i j k l}
$$

where $Y_{i j k l}$ is the observed measurement (growth, survival, gas interchange), $\mu$ is the overall mean, $P_{i}$ is the fixed effect of the $\mathrm{i}^{\text {th }}$ population (interior and coastal), $G(P)_{i j}$ is the fixed effect of the $\mathrm{j}^{\text {th }}$ breeding generation (first to third) nested within the $\mathrm{i}^{\text {th }}$ population, $F(G(P))_{i j k}$ is the random effect of the $\mathrm{k}^{\text {th }}$ family (1 to 30$)$ nested within the $j^{\text {th }}$ breeding generation and nested within the $\mathrm{i}^{\text {th }}$ population and $e_{i j k l}$ is the experimental random error.

\section{Growth and survival}

No population effects were observed for any of the traits $(P>0.05)$; however, breeding-generation effects were significant for height and diameter $(P<0.05$, Table 1$)$. Both populations showed a very consistent progressive increase between breeding generations. Taller and thicker plants were observed in the second breeding generation of the interior population, whereas the

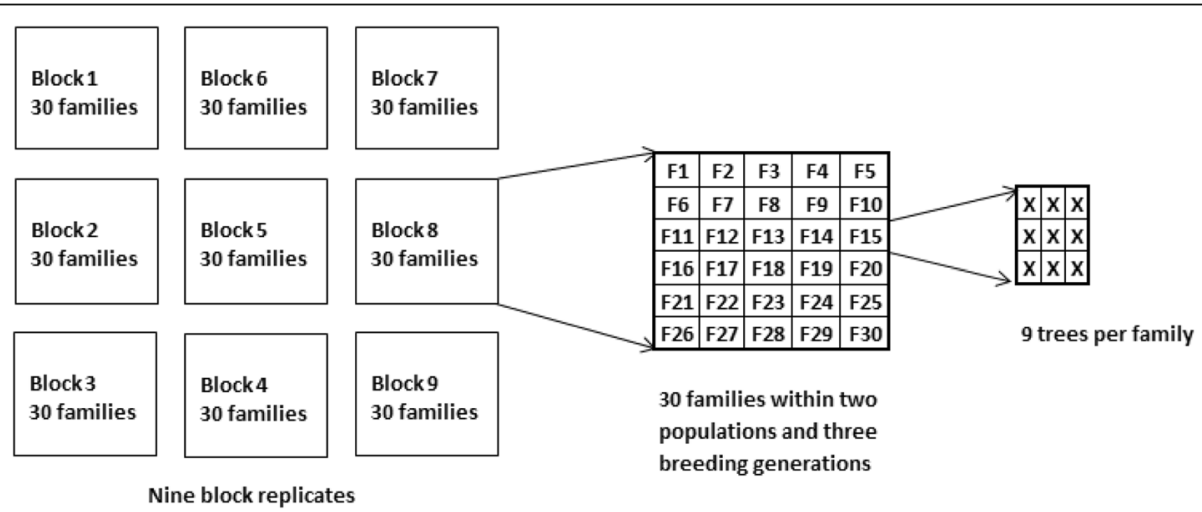

Fig. 1 Schematic diagram for field trial layout. Families were randomised within blocks 


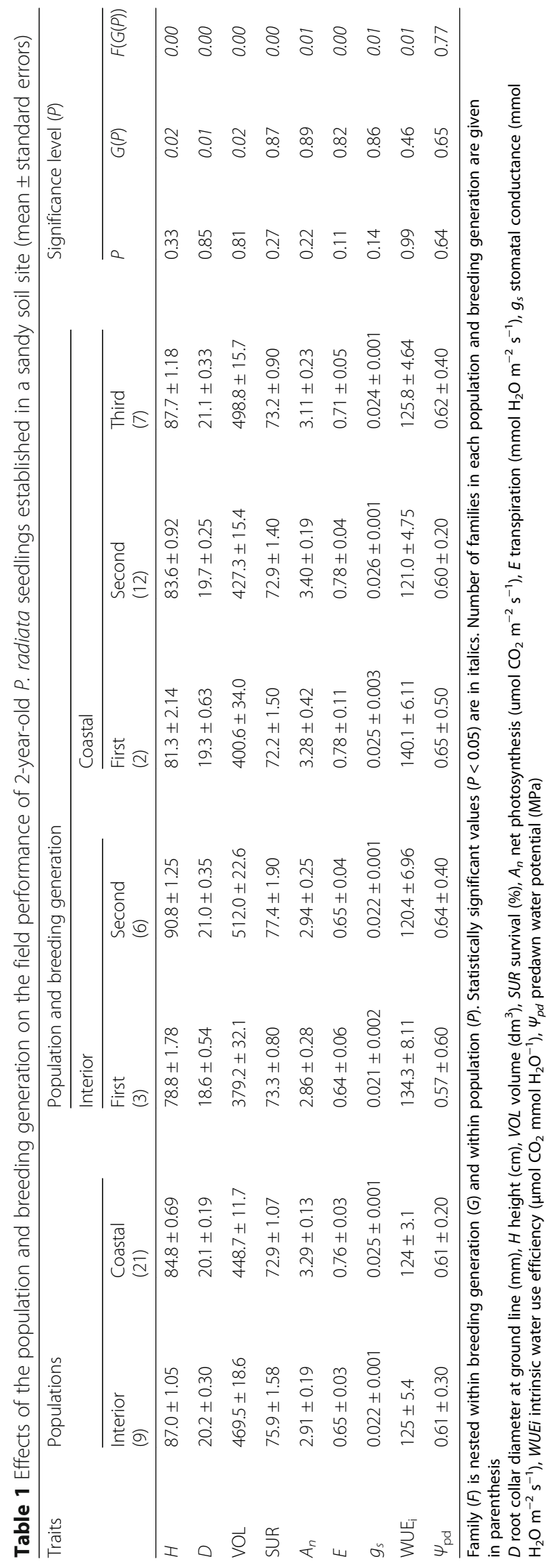


coastal population experienced a moderate change between generations of breeding.

\section{Gas-exchange traits}

For gas-exchange traits, significant differences $(P<0.05)$ were observed only among breeding families nested within generations within populations (Table 1). First-breedinggeneration families showed lower values of photosynthesis, stomatal conductance and transpiration than families from the second breeding generation. In the case of WUEi, peak values occurred in the first generation of breeding for both populations, when stomatal conductance was low in comparison with the second generation of breeding; however, the overall generations-withinpopulations effect was non-significant $(P=0.14)$. Predawn needle water potentials were low, and no differences were observed in any of the factors assessed $(P>0.05)$.

\section{Discussion}

\section{Growth and survival}

As expected, a significant increase in growth in the second generation was observed compared with the unimproved first generation, as a presumed consequence of selection on growth traits. This accords with the fact that families used in this study were originally selected for Forestal Mininco Company for their superior diameter and height growth. While $P$. radiata seedlings often reach a height of $2 \mathrm{~m}$ in the second year after establishment (Lisboa 1993; Mead 2013), we attribute the low level of growth in this study to the very low soil moisture availability at the planting site. On the other hand, although families used in this study came from contrasting ecological origins, population differences in survival, diameter and height were not obvious, which may be attributable to the fact that the Chilean tree improvement programme has selected families that perform well across a wide range of sites. Breeders have usually aimed to develop genotypes that are satisfactory for a wide range of conditions (i.e. showing low genotype $\times$ environment interaction in field trials); however, care must be taken when maximising growth rates with second- or third-breeding-generation trees in droughtprone sites. This seems to be an adequate long-term strategy only if high growth, leaf areas and transpiration can be supported in years of significantly below-average rainfall. Effects of native-population origins could have also contributed to family differences. As the two regional breeding populations used in our study would both have had some mix of Monterrey and Año Nuevo populations (Burdon 1978), that would tend to not only create some initial difference in adaptive profiles of the regional breeding populations but also create a source of family variation within those populations. On the other hand, the Pearson's correlation coefficient between nursery and field conditions, based on family mean for height, was moderate and negative $(R=-0.40, P=0.02)$, indicating a low correspondence between both environments. Only two families retained the same quantile ranking in the two environments (details not shown).

\section{Gas exchange}

Breeders of $P$. radiata in Chile have focused on selecting taller trees. However, three generations of breeding of highly productive $P$. radiata individuals could have resulted in an increased photosynthesis rate, a response also related to the unintended changes associated with breeding in Chile (Espinoza et al. 2014). Therefore, we expected unimproved generations to have somewhat lower physiological performance than improved ones. However, no statistical differences were observed when genotypes selected for adaptation to contrasting site conditions (i.e. coastal vs. interior families) were compared. In principle, this may be attributable to the fact that most of the genotypes were coastal selections (i.e. $70 \%$ of the families under study) belonging to the second generation of breeding ( $60 \%$ of the families under study). Also, the lack of statistical difference in predawn water potential among the different materials of our study could be explained by the fact that the site was far from fully occupied by any vegetation and trees were not yet severely water stressed given that $\Psi_{\mathrm{pd}}$ was above -1.0 MPa. In contrast, Sands and Nambiar (1984) and Watt et al. (2003) reported severe water stress in young P. radiata trees growing with weed competition (i.e. $\Psi_{\mathrm{pd}}$ below -2.0). This effect was attributed by both sets of authors to the competition by weeds for water.

No clear differences in physiology could be found by comparing net photosynthetic rates from studies involving unimproved P. taeda seedlings (Cregg et al. 1993) and improved family varieties (McGarvey et al. 2004). Similarly, it seems that three generations of breeding of $P$. radiata with truncation selection applied to the species have not substantially changed phenotypic variability for the ecophysiological traits, which could be advantageous under changing environmental conditions, since resource capture and stand productivity could be greater (Bettinger et al. 2009). On the other hand, high levels of genetic diversity of the species (Espinoza et al. 2012) could have also improved the buffering capability against environmental stresses, which may result in a more uniform physiological performance.

The statistically marginal decrease in WUEi when populations are passing from one breeding generation to the next could be explained because they were historically selected and bred on the basis of growth rate and might be expected to be highly carbon demanding. For instance, taller Pinus ponderosa Douglas ex C. Lawson trees had lower water use efficiency (Cregg et al. 2000). 
Some studies have found a significant positive relationship between growth and carbon fixation (Boltz et al. 1986). However, our WUEi results must be interpreted with caution because they represent only one instantaneous measurement made in small trees, which could well be poor predictors of long-term yield potential. Other techniques, such as the use of $\delta^{13} \mathrm{C}$ discrimination may provide a more integrated measure of water use efficiency for the selection of genotypes (Condon et al. 2004). Also, the maturation stages of our families could have biased our results as they probably showed heritable differences (Burdon et al. 1992a, b), despite fact that the trees in our study were "apparently" in the same maturation stage (by visual inspection only) and were still young and short (less than $1 \mathrm{~m}$ tall). Thus, it could be important to explore genetic control of WUEi and its genetic association with other leaf traits in response to water stress but combining instantaneous measurements with more integrated measures of water use efficiency, i.e. $\delta^{13} \mathrm{C}$. De Miguel et al. (2011) detected a moderate broadsense heritability for WUEi in Pinus pinaster Aiton $\left(H^{2}=\right.$ $0.15)$, and a significant genetic correlation between $g_{s}$ and specific leaf area (SLA), suggesting that selection based on needles with low SLA values will improve WUEi by reducing water losses through stomatal control.

\section{Conclusions}

The comparative analysis of plantations established with improved families of $P$. radiata as well as unimproved material showed growth gains between breeding generations, but no group differences for gas-exchange traits. However, it is difficult to draw firm conclusions from this study because it was based on local observations and short-term measurements made on a limited and unbalanced number of families. Drought is an important environmental factor in Mediterranean ecosystems that affects seedling survival and productivity. Therefore, breeding effects on physiology (e.g. water use efficiency) should be evaluated in order to quantify the global differences among commercial seed lots or clones compared with unimproved material. The effects on the stand-level productivity should also be examined, especially when establishing plantations on drought-prone sites, as we do not yet know what variation in physiological traits means in terms of field performance of $P$. radiata in Chile.

\section{Acknowledgements \\ This research was granted by CONICYT (Project No. 11121484). The first author was granted by CONICYT grant no. 79150013. We gratefully acknowledge Dr. Verónica Emhart and Mr. Alex Medina from Forestal Mininco S.A. for supplying the seeds to carry out this experiment and for field trial establishment.}

\section{Authors' contributions}

SE wrote the manuscript and carried out field monitoring. CM contributed to research design. MY supported the field measurements and physiological determinations and contributed to paper preparation. RS, AC, RR and MI provided critical revisions of the manuscript. All authors read and approved the final manuscript.

\section{Competing interests}

The authors declare that they have no competing interests.

\section{Publisher's Note}

Springer Nature remains neutral with regard to jurisdictional claims in published maps and institutional affiliations.

\section{Author details}

${ }^{1}$ Facultad de Ciencias Agrarias y Forestales, Universidad Católica del Maule, Avenida San Miguel, 3605 Talca, Chile. ${ }^{2}$ Facultad de Ciencias Forestales y de la Conservación de la Naturaleza, Universidad de Chile, Avenida Santa Rosa, 11365, La Pintana, Santiago, Chile. ${ }^{3}$ Facultad de Ciencias Forestales,

Universidad de Concepción, Victoria 631, Barrio Universitario, Concepción, Chile. ${ }^{4}$ Centro Tecnológico del Álamo, Universidad de Talca, Avenida Lircay s/n, Talca, Chile. ${ }^{5}$ Southern Tree Breeding Association Inc, Mt. Gambier, SA 5290, Australia.

Received: 20 October 2016 Accepted: 25 May 2017

Published online: 12 June 2017

\section{References}

Albert, F. (1900). Las Dunas O Sean Las Arenas Volantes, Voladeros, Arenas Muertas, Invasión de las Arenas, Playas I Médanos del Centro de Chile. In Comprendiendo el Litoral Desde el Norte de la Provincia del Aconcagua Hasta el Límite Sur de la de Arauco. Santiago: Cervantes [in Spanish]

Bettinger, P., Clutter, M., Siry, J., Kane, M., \& Pait, J. (2009). Broad implications of southern United States pine clonal forestry on planning and management of forests. International Forestry Review, 11, 331-345.

Boltz, B. A., Bongarten, B. C., \& Teskey, R. O. (1986). Seasonal patterns of net photosynthesis of loblolly pine from diverse origins. Canadian Journal of Forest Research, 16, 1063-1068.

Burdon, R. D. (1978). Mejoramiento genético forestal en Chile. CONAF-FAO. In FO. DP/CHI/76/003. Documento de Trabajo Nº 11 (p. 81) [in Spanish].

Burdon, R. D., Bannister, M. H., \& Low, C. B. (1992a). Genetic survey of Pinus radiata. 2: population comparisons for growth rate, disease resistance, and morphology. New Zealand Journal of Forestry Science, 22, 138-159.

Burdon, R. D., Bannister, M. H., \& Low, C. B. (1992b). Genetic survey of Pinus radiata. 3: Variance structures and narrow-sense heritabilities for growth variables and morphological traits in seedlings. New Zealand Journal of Forestry Science, 22, 138-159.

Camus, P. (2006). Ambiente, bosques y gestión forestal en Chile 1541-2005. Santiago: Diban LOM [in Spanish].

Condon, A. G., Richards, R. A., Rebetzke, G. C., \& Farquhar, G. D. (2004). Breeding for high water-use efficiency. Journal of Experimental Botany, 55, 2447-2460.

Contesse, G. D. (1987). Apuntes y consideraciones para la historia del pino radiata en Chile. Boletín de la Academia Chilena de la Historia, 97, 351-373 [in Spanish].

Cregg, B. M., Teskey, R. O., \& Dougherty, P. M. (1993). Effect of shade stress on growth, morphology, and carbon dynamics of loblolly pine branches. Trees, 7, 208-213.

Cregg, B. M., Olivas-García, J. M., \& Hennessey, T. C. (2000). Provenance variation in carbon isotope discrimination of mature ponderosa pine at two locations in the Great Plains. Canadian Journal of Forest Research, 30, 428-439.

De Miguel, M., Sánchez-Gómez, D., Cervera, M. T., \& Aranda, I. (2011). Functional and genetic characterization of gas exchange and intrinsic water use efficiency in a full-sib family of Pinus pinaster Ait. in response to drought. Tree Physiology, 32, 94-103.

Espinoza, S., Magni, C. R., Martinez, V., Gapare, W., \& Cordero, C. (2012). Genetic diversity and differentiation of Chilean land race of Pinus radiata $D$. Don using microsatellite DNA markers. Silvae Genetica, 61(6), 221-228.

Espinoza, S. E., Magni, C. R., Martínez, V. A., \& Ivković, M. (2013). The effect of water availability on plastic responses and biomass allocation in early growth traits of Pinus radiata D. Don. Forest Systems, 22, 3-14.

Espinoza, S. E., Martínez, V. A., Magni, C. R., Ivković, M., Santelices, R. E., \& Cabrera, A. M. (2014). Genetic control of growth, biomass allocation and survival under drought stress in Pinus radiata D. Don seedlings. Tree Genetics and Genomes, 10(4), 1045-1054. 
Espinoza, S. E., Magni, C. R., Santelices, R. E., Ivković, M., \& Cabrera, A. M. (2016). Changes in drought tolerance of Pinus radiata in Chile associated with provenance and breeding generation. Annals of Forest Science, 73, 267-275. Ginn, S. E., Seiler, J. R., Cazell, B. H., \& Kreh, R. E. (1991). Physiological and growth responses of eight-year-old loblolly pine stands to thinning. Forest Science, 37, 1030-1040.

Huber, A., \& Trecaman, R. (2004). Eficiencia del uso del agua en plantaciones de Pinus radiata en Chile. Bosque, 25(3), 33-43 [in Spanish].

Li, L., \& Wu, H. X. (2005). Efficiency of early selection for rotation-aged growth and wood density traits in Pinus radiata. Canadian Journal of Forest Research, $35,2019-2029$.

Lisboa, H. B. (1993). The Chilean radiata pine sector. In N. B. Lewis \& I. S. Ferguson (Eds.), Management of radiata pine (pp. 365-379). Melbourne: Inkata Press.

McGarvey, R. C., Martin, T. A., \& White, T. L. (2004). Integrating within crown variation in net photosynthesis in loblolly and slash pine families. Tree Physiology, 24, 1209-1220.

Mead, D. J., (2013). Sustainable management of Pinus radiata plantations. FAO Forestry Paper No. 170. Food and Agriculture Organization of the United Nations, Rome

Sands, R., \& Nambiar, E.K.S. (1984). Water relations of Pinus radiata in competition with weeds. Canadian Journal of Forest Research, 14, 233-237.

Watt, M.S., Whitehead, D., Mason, E.G., Richardson, B., \& Kimberley, M.O. (2003). The influence of weed competition for light and water on growth and dry matter partitioning of young Pinus radiata, at a dryland site. Forest Ecology and Management, 183, 363-376.

Yang, W. Q., Murthy, R., King, P., \& Topa, M. A. (2002). Diurnal changes in gas exchange and carbon partitioning in needles of fast- and slow growing families of loblolly pine (Pinus taeda). Tree Physiology, 22, 489-498.

\section{Submit your manuscript to a SpringerOpen ${ }^{\circ}$ journal and benefit from:}

- Convenient online submission

- Rigorous peer review

- Open access: articles freely available online

- High visibility within the field

- Retaining the copyright to your article

Submit your next manuscript at $\boldsymbol{s p r i n g e r o p e n . c o m ~}$ 